\title{
Site fidelity and movement patterns of short-finned pilot whales within the Canary Islands: evidence for resident and transient populations
}

SERVIDIO A.* 1,2,3; PÉREZ-GIL E. ${ }^{1,3}$; PÉREZ-GIL M. ${ }^{1,3}$; CAÑADAS A. ${ }^{4}$; HAMMOND P.S. ${ }^{2}$; MARTÍN V. ${ }^{1}$

${ }^{1}$ Society for the Study of Cetacean in the Canary Archipelago (SECAC); mailing box 49, 35500 Arrecife, Lanzarote, Canary Islands, Spain.

${ }^{2}$ Sea Mammal Research Unit, Scottish Oceans Institute, University of St Andrews, Fife, KY16 8LB, Scotland, UK.

${ }^{3}$ CEAMAR, Cetacean and Marine Research Institute of the Canary Islands; 35509 Playa Honda, Lanzarote, Canary Islands, Spain.

${ }^{4}$ Alnilam Research and Conservation, 28491 Navacerrada, Madrid, Spain

\section{ABSTRACT}

2 1. The geographic location and oceanographic, physical and chemical water properties make the

3 Canary Islands one of the planet's biodiversity hotspots. The short-finned pilot whale (SFPW,

4 Globicephala macrorhynchus) is one of the archipelago's most commonly encountered species and

5 is potentially vulnerable to a range of anthropogenic pressures including habitat degradation,

6 acoustic pollution, fishing, whale-watching operations and shipping. Assessment of impact has not

7 been possible because of a lack of even basic information about occurrence and distribution.

8 2. Spatial and temporal distributions, ranging behaviour and residence patterns of short-finned pilot

9 whales were explored for the first time using survey and photo-identification data collected in the

10 Canary Islands between 1999 and 2012. In total, 1,081 pilot whale sightings were recorded during

$1170,620 \mathrm{~km}$ of search effort over 1,782 survey days.

3. Pilot whales were detected year-round and distributed non-uniformly within the archipelago, with greater densities concentrated in patchy areas mainly on the leeward side of the main islands. In total, 1,320 well-marked individuals were identified, which exhibited a large degree of variability in site fidelity. 
16 4. Different but not isolated sub-populations of pilot whales that share ranges and maintain social 17 interactions are apparently present in the Canary Islands. Strong evidence of an island-associated 18 sub-population was found, with a group of 50 "core resident" individuals associated particularly 19 with Tenerife. There are also "transient" individuals or temporary migrants, which, probably driven 20 by inter- and intraspecific competition, may travel long distances whilst using the archipelago as 21 part of a larger range.

22 5. These findings fill a major gap in the knowledge of this species occurrence, distribution, 23 movements and site fidelity in the archipelago and provide much needed data to allow the initiation 24 of informed conservation assessments and management actions.

25 Keywords: Archipelago, ocean, island, distribution, survey, environmental impact assessment, 26 mammals

27 *Corresponding author: Dr. A. Servidio; Tel.: +39 3935674353; E-mail: antonella@ ceamar.org 


\section{INTRODUCTION}

The analysis and description of space-use patterns have been crucial in understanding the ecology of many mammalian populations (Adams \& Davis, 1967; Inglis, Hood, Brown, \& DeYoung, 1979), providing important insights into animals’ residency (T. H. Clutton-Brock, 1989), social organization (Ostfeld, 1990), demography (T. Clutton-Brock \& Albon, 1985) and distribution of animals' resources in space and time (Brown \& Orians, 1970). Studies to increase our understanding of the drivers and scale of animal movement are integral components of the information needed to manage human impacts on wild cetaceans (Hastie et al., 2003; Hooker, Whitehead, \& Gowans, 1999; Ingram \& Rogan, 2002; Wilson, Thompson, \& Hammond, 1997).

Individuals of most species are not distributed randomly and do not use all parts of their range with the same intensity. Instead, some areas are used more frequently (Adams \& Davis, 1967; Dixon \& Chapman, 1980) or differently (feeding, calving, etc.; Burt, 1943), forming characteristic patterns of distribution, grouping, ranging, and association (Crook, Ellis, \& Goss-Custard, 1976). Intra- or inter-specific competition for the same resources in the same niche is one factor that may lead to differential space use among individuals (Milinski \& Parker, 1991).

In general, an animal's range should be large enough to provide adequate food resources to satisfy energetic requirements (McNab, 1963) and there is a strong correlation between range size and the way space within range is used, and the abundance, distribution, and predictability of food resources (Davies \& Houston, 1994). Where food resources are abundant and no aggressive territorial neighbours are present, animals tend to use only as much as space as they need (King, 2002), and to stay in familiar areas rather than risk moving to other areas, even if they are more productive (Switzer, 1993). If resources are uniformly spread throughout an area, animals also tend to be uniformly distributed and, if the resources are defendable, often show territoriality behaviour (Emlen \& Oring, 1977). In less productive habitat and in areas characterised by patchy or limited resources, animals tend to have larger and overlapping ranges (Harestad \& Bunnel, 1979) because they must travel farther to obtain enough food (T. Clutton-Brock, 1975; Schoener, 1968).

Marine mammals live in fluid, open environments with few boundaries, feed on mobile prey, and have low transport costs per unit weight (Williams, 1999). Consequently, they are highly mobile and tend to have larger ranges than terrestrial mammals of similar size (Tucker, Ord, \& Rogers, 2014). Delphinids show a wide variety of site fidelity and ranging patterns; individuals may occupy large ranges or be restricted in smaller areas; some display year-round residency patterns while 
others are seasonal or "transient" visitors (Hunt et al., 2017; McGuire \& Henningsen, 2007; Parra, Corkeron, \& Marsh, 2006; Silva et al., 2008; Zanardo, Parra, \& Möller, 2016)

Pilot whales (genus Globicephala) are highly mobile and have been described as generally nomadic, without defined migrations (Olson, 2009). Some north-south and seasonal inshoreoffshore movements related to prey movements or incursions of warm water have been, anyhow, described for long-finned pilot whales (Globicephala melas) (Abend \& Smith, 1999; Cañadas \& Sagarminaga, 2000; De Stephanis, Verborgh, et al., 2008).

The strong genetic differentiation between short-finned pilot whales (SFPWs, Globicephala macrorhynchus) found in different oceans, between populations in Japan (Oremus et al., 2009) and within the Pacific Ocean, suggest regional population structure and restricted movements within ocean basins (e.g. Van Cise et al., 2016). Areas of continental shelf break with steep bathymetric features and submarine canyons represent important feeding habitat for coastal short-finned pilot whales, which have restricted ranges in the context of the basin-wise distribution of the species (Thorne et al., 2017).

The stable presence of this species has been described in the oceanic and volcanic archipelagos of Hawaii (Mahaffy, Baird, McSweeney, Webster, \& Schorr, 2015), Madeira (Alves et al., 2013) and the Canary Islands (Carrillo, Pérez-Vallazza, \& Álvarez-Vázquez, 2010; Heimlich-Boran, 1993). A considerable variability in residency patterns has been found, with some animals showing little site fidelity but others exhibiting long-term fidelity to the main islands (Alves et al., 2013; Mahaffy et al., 2015).

Previous studies of this species have found a stable presence in southwest Tenerife (Escorza, Heimlich-Boran, \& Heimlich-Boran, 1992; Heimlich-Boran, 1993; Montero \& Arechavaleta, 1996) but there is very little information about spatial and temporal distribution patterns in that area or about their occurrence in other parts of the archipelago.

The waters around the Canary Islands include localised areas rich in nutrients (Arístegui et al., 2006; Arístegui et al., 1989; Arístegui et al., 1997), which may provide suitable habitat and sufficient resources to support one or more "resident" populations of SFPWs. Such populations would be expected to show high fidelity to local areas and limited ranging behaviour (Habel, Hillen, Schmitt, \& Fischer, 2016; King, 2002). Conversely, areas where resources are limited or available intermittently may only be suitable for whales that range over greater distances utilising a wider range of areas/habitats (Harestad \& Bunnel, 1979; Silva et al., 2008). 
SFPWs are subject to a range of pressures from human activities in the Canary Islands. Habitat degradation, deliberate and accidental discharge of pollutants into the sea, coastal development, acoustic pollution, fishing activity, whale-watching excursions, and intensification of maritime traffic are all potential threats to the conservation of this species and other cetaceans that inhabit these waters year-round (Carrillo \& Ritter, 2010). This lack of even basic information about occurrence and distribution hampers assessment of the impact of human activities on local populations of this species and, therefore, conservation and management efforts.

In this study we use information on the distribution, occurrence patterns, individual sighting frequencies, movements and area use of SFPWs over 13 years in the Canary Islands to investigate whether there are coastal resident populations that can be distinguished from a more oceanic population that uses the waters of the archipelago less intensively. An improved understanding of spatio-temporal movements of SFPWs among the islands and the identification of any particularly important areas will help to describe this species ecology in the archipelago leading to a better understanding of its conservation status in the context of the multiple human pressures and facilitating assessment of the need for and development of management actions.

\section{MATERIAL AND METHODS}

\section{$\underline{\text { Study area }}$}

The study was conducted in the warm-temperate waters around the Canary Islands (area = 109,000 $\mathrm{km}^{2}$ ), an archipelago formed by seven independent volcanic islands (Carracedo, 2001) and various islets, with a total coastline of $1,500 \mathrm{~km}$. The archipelago is located in subtropical latitudes $27^{\circ}-30^{\circ}$ $\mathrm{N}$, on the continental rise off Cabe Juby, next to the northwest African coast, and belongs to the insular arc known as Macaronesia (Figure 1).

\section{Field procedures}

Surveys in the waters around the islands of the archipelago were conducted between 1999 and 2012. Survey transects were not systematic but were designed to cross depth contours in a zigzag pattern to provide homogeneous coverage of the whole bathymetric range (Figure 1). A wide variety of vessels was used, including small semi-rigid inflatable boats (survey length 41,218.5 km), opportunistic vessels (whale-watching; survey length 4,566.6 km), sailing boats (survey length 8,064.6 km), research vessels (survey length 43,559 km). Eight ferryboats "Naviera Armas" were 
119 also used as opportunistic platforms (survey length 12,361.3 km) between the islands of La 120 Gomera, Tenerife, Gran Canaria, and Fuerteventura (Figure 1).

121 Each research platform was always provided with the minimum required set of research equipment (GPS recorder, 7x50 binoculars, digital cameras high definition video camera, hydrophone, and a

$123125 \mathrm{lb}$ power crossbow), and had a minimum of two trained researchers. From different platform 124 heights, depending on the vessel, two observers simultaneously scanned the horizon covering a $125180^{\circ}$ sector in front of the boat $\left(90^{\circ}\right.$ each). When a cetacean or a group of cetaceans was detected, 126 searching effort was suspended and data were collected from the group. A "group" was defined as a 127 spatial aggregation of animals, within 1,000 $\mathrm{m}$ of each other, that showed similar behavioural activity and interacted with one another over timescales sufficiently short that there were few (or no) changes in group membership (Karczmarski, Würsig, Gailey, Larson, \& Vanderlip, 2005). For each encounter, time, GPS position, species, estimated radial distance to the detected group, and group size were recorded. On dedicated research vessels, behavioural observations and group composition were also recorded, and photo-identification and biopsy sample collection conducted.

A photographic coverage percentage was assigned in the field, based on the estimated approximate proportion of animals photographed that were observed at sea. Only sightings where the data collection protocol was considered completed at sea were included in the group size estimation and group composition analyses. Based on the data provided by Kasuya and Marsh (1984) and following Heimlich-Boran (1993) interpretations, age/sex classes were defined as: adult male (never found in association with a calf, with a minimum length of $4 \mathrm{~m}$ at maturity and a maximum length of $5.8 \mathrm{~m}$ ), indeterminate (adult female or sub-adult male which did not have a consistent association with a specific immature animal), female (individuals with the physical characteristics of an indeterminate whale and in association with a calf for the entire duration of a sighting), juvenile (animals between 2.5 and $3 \mathrm{~m}$ in length, with little developed dorsal muscle); calf (whale with a length between one third and half of an indeterminate animal) neonate (calves for which it was possible to distinguish foetal marks on the body).

Data analysis

\section{Photo-identification}

The photographic material included both colour slides and digital images. All photographic sorting/matching was done visually using Adobe Bridge CS5 software. Focus, contrast, parallax, and relative size of dorsal fin (used for identification - see below) in the picture were used to grade 
picture quality (Arnbom, 1987; Dufault \& Whitehead, 1993, 1995) from "poor" (1) to "excellent" (4) (Baird, Gorgone, et al., 2008; Baird, Webster, et al., 2008; McSweeney, Baird, Mahaffy, Webster, \& Schorr, 2009). Individual SFPWs were identified from photographs of their dorsal fins showing naturally occurring marks and notches that allowed left- and right-side photographs to be matched.

Dorsal fin silhouettes and scars on the dorsal fin (Bernd Würsig \& Thomas A. Jefferson, 1990; Würsig \& Würsig, 1977) were used as secondary features to confirm matches and to sort individuals without notches. All the principal matching was conducted by the same person (AS) and an experienced researcher reviewed the final photo-identification catalogue to minimise the chance of false-positive and false-negative matches.

Each identified individual was classified for its overall distinctiveness based on its dorsal fin characteristics: number, size and shape of nicks, notches and scars on the leading and the trailing edge of the dorsal fin. The rating followed the ranking scale of 1 to 4 , from "not distinctive" to "very distinctive" (Mahaffy et al., 2015). Photo-identification catalogues with the best picture of each animal (from one or both sides) associated with each island were compiled and compared. As many features as possible were used to confirm matches and reduce the possibility of false positives (Scott, Wells, Irvine, \& Mate, 1989; Williams, Friedl, \& Haun, 1993; Bernd Würsig \& Thomas A Jefferson, 1990). The rate of mark change and mark acquisition was assessed by examining images of fins for new notches or changes in notch shape in all re-sightings of individuals. Only good quality photographs (categories 3 and 4) and well-marked animals (distinctiveness 3 and 4) were used in the residency analyses because an assumption of equal capture probability was required. Multiple photographs of the identified individuals were examined to confirm the age-sex classification. In encounters for which the group size estimate at sea was found to be smaller than the number of individuals identified, the sample size obtained by photo-analyses was used as the approximate encounter group size.

\section{Occurrence patterns}

Occurrence patterns and distribution were described by considering the number of pilot whale sightings observed and their distribution in relation to the survey location and frequency. To account for the uneven geographical distribution of the survey effort, the study area was divided into a grid of $160 \times 61$ cells in the range $27^{\circ} 28^{\prime} \mathrm{N}$ to $29^{\circ} 30^{\prime} \mathrm{N}$ latitude and $12^{\circ} 58^{\prime} \mathrm{W}$ to $18^{\circ} 18^{\prime} \mathrm{W}$ longitude. Cell area varied between 11.89 and 12.14 square kilometres. The average encounter rate was calculated by dividing the total number of sightings made on effort in each grid cell by the sum 
182

of the distance in kilometres covered on effort in each cell. Cells with a total survey effort less than $1.414 \mathrm{~km}$ (diagonal of a $1 \mathrm{~km}^{2}$ ) in any given year were excluded, resulting in a set of 1,598 grid cells used for the analyses.

The non-parametric Mann-Whitney $U$ test was used to check if significant differences in group size existed among islands, seasons, and type of groups (male/female and residency patterns).

\section{Residency and site fidelity}

Four different residency categories were created based on individual re-sighting rates across the whole archipelago, with sampling intervals defined by month and year: "core resident" (SFPWs sighted at least once during each of the four different seasons of at least four different years), "resident" (individuals seen in three or four years and at least two seasons), "occasional" (temporary migrant seen less frequently than "residents", but more than twice), "transient" (whales sighted once or twice in only one season in only one year).

\section{Lagged identification rate}

SFPWs residence rate was measured by calculating the lagged identification rate (LIR), which represents the probability that an individual identified at any particular time will be identified again in the study area $t$ time units later (Whitehead, 2001). LIR computation and model fitting were applied to all sightings of all animals and were carried out using the computer software SOCPROG 2.4. (Whitehead, 2009) in MATLAB. Models were fitted to the data using maximum likelihood and binomial loss (Whitehead, 2001), and the quasi Akaike Information Criterion (QAIC) was used to select the best-fitting model (Burnham \& Anderson, 2003). The analysis was conducted using a sampling period of 1 day. Jack-knife techniques with 1,000 bootstrap replications were used to calculate confidence intervals and standard errors for each model parameter. Three residency models were fitted to the residency rate data: "closed" (no changes in the individuals present in the area), "emigration/mortality" (individuals could leave the area but never return), "emigration and re-immigration" (individuals could leave and then re-enter the area; Whitehead, 2009; Whitehead \& Waters, 1990; Supplementary Material Table S1). Plots of LIR against time were produced for all identified whales in the archipelago and also focusing only on waters off Tenerife to provide indications of the temporal use of the area by individual animals. Movements between Tenerife and La Gomera waters were also analysed.

\section{Ranging patterns}


212 Movements represented by re-sightings of identified whales within the archipelago were

213 documented. Linear distance between consecutive re-sightings of photo-identified individuals was

214 measured in GIS software using the "shortest straight swim" distance.

215 GIS software ArcView 3.2 with the Animal Movement extension (Hooge \& Eichenlaub, 1997) was 216 used to determine the size of individual ranges and to examine individual ranging patterns. The 217 analysis was performed using the kernel estimator (B. J. Worton, 1989), a probabilistic non218 parametric method that attempts to assess the animal's use distribution (UD) within an area 219 (Kernohan, Gitzen, \& Millspaugh, 2001) by quantifying the likelihood of finding the animal at any 220 particular location within its range (B. J. Worton, 1989). To decide the minimum number of 221 sightings required in the ranging analysis, bootstrap tests on Minimum Convex Polygon (MCP) range size were run and the shape of the curve relating the size of the ranging area to the number of locations was inspected for each whale. Least-squares cross-validation (LSCV) was used to calculate the bandwidth value (which determines the amount of smoothing applied to the data), and the harmonic mean outlier removal method (White \& Garrott, 2012) was applied to identify and remove outlying locations. To minimise autocorrelation (Swihart \& Slade, 1985; B. Worton, 1987) multiple sightings of the same individual on the same date were eliminated from the datasets used to determine individual range size and ranging patterns. Schoener's ratio (Schoener, 1981) was calculated for each individual to assess the amount of autocorrelation remaining in the data and the potential effect on the estimates of range size.

\section{RESULTS}

Between January 1999 and October 2012, 1,782 day-surveys were conducted around the different islands of the archipelago. In total, 109,770 km were covered (10,307 hours), within which 70,620 $\mathrm{km}$ were spent on effort (5,436 hours) by dedicated survey vessels (Figure 1). Searching effort over the whole Canary archipelago did not vary significantly over years (Kruskal-Wallis test, H2 = $15.985, \mathrm{p}=0.192$ ) or seasons (Kruskal-Wallis test, $\mathrm{H} 2=6.093 ; \mathrm{p}=0.107$ ). However, the amount of searching effort was not evenly spread amongst different islands in terms of time, distance or area searched (Table 1; Figure 1). The downwind areas of Lanzarote and Fuerteventura were surveyed for 13 years, Tenerife and Gran Canaria for 11 years, La Gomera for 6 years and La Palma and El

241 (42\% of the total time); the remainder was mostly spread evenly around the islands of

242 Fuerteventura, Lanzarote, Tenerife and La Gomera (Table 1). 
In total, 4,242 sightings of 23 cetacean species were recorded. The SFPW was the most frequently seen species, with 1,081 sightings (Figure 2, Table 1). SFPWs were encountered during every daysurvey conducted in the waters off Tenerife, with a mean encounter rate (sightings per grid cell) of $2.16(\mathrm{SE}=0.38)$ sightings $100 \mathrm{~km}^{-1}(n=150)$ surveyed (Supplementary Material Table S2).

Significantly fewer sightings were recorded around the other islands (Kruskal-Wallis test, H2 = 172.044, $\mathrm{p}<0.001)$, from a mean of $0.64 \pm 0.19$ sightings $100 \mathrm{~km}^{-1}$ off La Gomera $(n=54)$ to 0 off El Hierro (Supplementary Material Table S2). On 167 occasions they were found associated with other delphinid species, especially with Tursiops truncatus (147 sightings) and Stenella frontalis (15 sightings). SFPWs were sighted in a wide range of depths, mostly between the $900 \mathrm{~m}$ and 1200 $\mathrm{m}$ isobaths $(1077.5 \pm 16.9 \mathrm{~m}, n=621)$, and were found in shallower waters in La Gomera compared to Tenerife and Lanzarote-Fuerteventura (Mann-Whitney $U$ test, $U=7,162, p=0.006 ; U=90$, $\mathrm{p}<0.001$, respectively). The distance of sightings from the coast $(5.76 \pm 0.14 \mathrm{~km}, n=625)$ varied among islands, with greater distances in the eastern islands of Lanzarote-Fuerteventura and Gran Canaria, compared to Tenerife (Mann-Whitney $U$ test, $U=1,572, p<0.001 ; U=1,432, p<0.001$, respectively) and to La Gomera and La Palma (Mann-Whitney $\mathrm{U}$ test, $\mathrm{U}=114, \mathrm{p}<0.001 ; \mathrm{U}=111$, $\mathrm{p}=0.002$, respectively).

Initial behaviour recorded during the study period included all behavioural categories, which were all observed year-round with no marked differences in frequency, except for socialising which was observed for $77 \%$ of the time from June to October.

\section{Group size and composition}

Group size ranged from one to 80 individuals, with an overall mean group size of $16 \pm 0.4$ individuals $(n=810)$. Significantly larger groups were observed in La Gomera $(19 \pm 1.5)$ than in Tenerife (16 \pm 0.5) (Mann-Whitney, $\mathrm{U}=21861.5$, $\mathrm{p}=0.015)$, and in Gran Canaria (Mann-Whitney, $\mathrm{U}=1022.5, \mathrm{p}=0.013)$, and smaller group sizes were seen in Gran Canaria (13 \pm 1.3$)$ compared to Lanzarote-Fuerteventura (20 \pm 2.4 ; Mann-Whitney, $U=443.5, p=0.033$; Supplementary Material Figure S1a). Seasonal differences in group size were detected only in Tenerife, where observed group sizes were larger in summer and autumn than in spring (Mann-Whitney $U$ test, $U=11,535, p$ $=0.015 ; \mathrm{U}=11,631.5, \mathrm{p}=0.003$, respectively, Supplementary Material Figure S1b). Group composition showed that SFPWs commonly travel in groups of mixed sex and age. A high frequency of sightings with calves and/or neonates was recorded throughout the archipelago; $82 \%$ of the groups encountered included immature animals, with a mean per sighting of $1.3 \pm 0.06$ neonates/calves $(n=803)$. In Tenerife, where the majority of data were collected, the presence of 
neonates was highest during the summer months (52\%) followed by autumn (31\%). Neonates were present in the same groups as presumed adult males in 58.9\% of the recorded sightings. Group sizes of sightings with only males $(7 \pm 0.9, n=33)$ were significantly smaller than sightings with no adult males $(19 \pm 0.92, n=170$; Mann-Whitney $\mathrm{U}$ test, $\mathrm{U}=774.500, \mathrm{p}<0.001)$, and when also adult female were present $(17 \pm 0.7, n=256$; Mann-Whitney $\mathrm{U}$ test, $\mathrm{U}=7,118, \mathrm{p}<0.001$;

Supplementary Material Figure S2a). Groups with immature animals were significantly larger (19 \pm $0.8, n=382)$ than groups in which only mature whales $(9 \pm 0.8, n=33)$ were present (MannWhitney U test, $\mathrm{U}=26,675.5$, $\mathrm{p}<0.001$; Supplementary Material Figure S2b).

\section{Photo-identification}

During the 629 encounters where photo-identification sessions were conducted, 234,350 photographs were taken, of which 190,340 were considered suitable for photo-identification analysis, based on the photographic quality criteria. The overall catalogue of all identified SFPWs in the whole archipelago contained 14,469 dorsal fin photographs belonging to 3,275 unique individuals, within which 1,310 were well-marked individuals identified from good and excellent quality pictures (Table 2). A discovery curve constructed from the overall database (Figure 3) showed continual recruitment of new individuals to the marked population throughout most of the study period (1999-2012), with a temporal plateau reached during 2008. Some levelling off was present in the discovery curve of well-marked individuals in La Gomera, although new well-marked individuals were sighted until the end of the study period in all areas (Supplementary Material Figure S3). A total of 617 (50\%) well-marked individuals were seen only once, 191 (15\%) twice, and $433(35 \%)$ whales three to 36 (one animal) times (Figure 4). Re-sighting intervals ranged from one day to 11.26 years $(112 \pm 3.6$ days, $n=971): 37.7 \%$ of the individuals were recaptured within one year, $25.3 \%$ in the following year, and $7.3 \%$ over a longer time span (four animals seen in ten years, and five in 11 years between two and seven times).

\section{Distinctiveness and mark change}

Considering only the mature population, the proportion of re-captured individuals increased as the level of distinctiveness increased, and the mean number of times an individual was re-captured also increased with distinctiveness: 1.5 for non-distinctive, 2.7 for slightly distinctive, 3.1 for distinctive, and 3.8 for very distinctive SFPWs. In total, eighty-two mark-acquisition events or mark-changes were recorded for 64 individuals, but only in seven cases did they result in a change in distinctiveness category. The mark-change rate was estimated to be once every 3.4 to 4.2 years. The 
low mark-change rate, along with the long-lasting presence of scars persisting over ten years (Servidio 2014), allowed the effect of mark-change to be considered negligible.

\section{Site fidelity and movement patterns}

In total, 1,241 well-marked mature SFPWs were classified based on their residency pattern analysis: 255 whales (21\%) were considered "residents", and 50 (4\%) "core residents", mainly photo-identified in Tenerife (Table 3). Lanzarote and Fuerteventura had almost exclusively "transient" whales, ten SFPWs were recaptured between two and three times in different years in the area ("occasionals"), and only two animals were recaptured between these western islands and Gran Canaria, 11 years apart. Two hundred and eighteen whales were detected at more than one island, of which 27 were identified in Tenerife, La Gomera and Gran Canaria. The "resident" and "core resident" SFPWs in La Gomera $(n=102)$ and Gran Canaria $(n=35)$ were all, except for three animals, also seen in Tenerife, a reflection of the high number of recaptures among these three islands (Table 3 and Supplementary Material Table S3). The highest within-area rate of resighting was recorded in the two sub-areas off southwest Tenerife and La Gomera, where some animals $(n=23)$ were documented as moving back and forth, with six animals showing such movements up to four times. Most of the re-captures of the animals moving between Tenerife and La Gomera (96\%) and between Tenerife and Gran Canaria (60\%) occurred during the warmer months of the year. All residency categories were observed throughout the year but "transient" frequencies were double during warmer months than in the rest of the year. Groups with a mixed composition of residency patterns were also encountered mostly (75\%) during summer and autumn. The size of groups formed only by "core residents" and "residents" were significantly smaller (15.6 $\pm 0.5, n=170)$ than groups containing individuals with a mix of residency patterns $(22.8 \pm 1.9, n=$ 80); Mann-Whitney $U$ test, $U=17,469.5, p=0.01)$.

The distance between consecutive sightings of photo-identified SFPWs was mostly less than $10 \mathrm{~km}$, but $1 \%(\mathrm{n}=38)$ of inter-sighting distances were between 100 and $170 \mathrm{~km}$, illustrating extensive movements of animals within the archipelago.

There was no sex-specific difference in the distances travelled by SFPWs (Mann-Whitney U test, U $=537,187, \mathrm{p}=0.725)$. However, differences were found among SFPWs of different residency categories (Kruskal-Wallis test, $\mathrm{H} 2=86.350, \mathrm{p}<0.001$ ), with the exception of "occasional" and "transient" animals that did not differ statistically (Mann-Whitney $U$ test, $U=2,028.5 ; p=0.775$ ). Shorter distances were recorded for "core resident" animals $(8.33 \pm 0.65 \mathrm{~km}, n=530)$, followed by 
"resident" animals $(13.76 \pm 0.62 \mathrm{~km}, n=1,317)$, and then by "transient" $(26.11 \pm 6.01 \mathrm{~km}, n=43)$ and "occasional" animals $(31.78 \pm 2.37 \mathrm{~km}, n=191)$.

\section{$\underline{\text { Lagged Identification Rates (LIR) }}$}

The best fitting model for the LIR within the entire archipelago was the "emigration + reimmigration" model (Figure 5). An estimated $254 \pm 10$ of the 1,241 identified whales used in this analysis spent an average of $531 \pm 24$ days in the Canary Islands before leaving for an average of $4,087 \pm 941$ days (Table 4), i.e. beyond the 4.5 years covered by the dataset used for the analysis. Nevertheless, analyses indicated strong over-dispersion in the data (variance inflation factor = 4.82), so results should be interpreted with caution; in particular, the variances of the parameter estimates were likely underestimated.

For south-west Tenerife, the best-fitting model was "emigration/mortality" (Table 4), which estimated that 279 of the 717 identified animals had a high level of residency to the area, staying around the island for an average of 2,049 days, a time that was also beyond the 4.5 years of the study. These data were also over-dispersed (variance inflation factor $=3.67$ ) and the results should be interpreted cautiously.

For movements between La Gomera and Tenerife, in both directions, the best model was "fully mixed" (Table 4), which is supported by the high number of recaptures recorded between the two areas (Supplementary Material Table S3).

\section{$\underline{\text { Ranging patterns }}$}

Based on the asymptote of the area observation curve, a minimum number of 10 sightings was determined to be an adequate sample size to estimate the size of an individual's range, resulting in a total of 193 animals being selected for this analysis. The small sample size did not allow temporal changes in range size and location to be examined. The mean Schoener's ratio was $1.54 \pm 0.03$ (Supplementary Material Table S4), which can be considered acceptable according to Kenward et al. (2001). The extent of temporal autocorrelation in the data was not investigated. The kernel method gave a mean $95 \%$ UD area of $355.90 \pm 39.86 \mathrm{~km}^{2}$, ranging from 46.13 to $3,673.79$, and a $50 \%$ UD core area of $76.95 \pm 8.62 \mathrm{~km}^{2}$ (Supplementary Material Table S4). Even though great variability was found in the estimated core areas (50\% UD) among animals, as shown by the high standard error, $71 \%$ of all core areas overlapped in a limited area of $57.7 \mathrm{~km}^{2}$ in southwest Tenerife 
and La Gomera (Figure 6a). While most of the individual ranges were limited only to southwest Tenerife (99\% of the 50\% UD areas and $75 \%$ of the $95 \%$ UD), the $95 \%$ UD showed multiple centres of activity between this area and the southwest areas of La Gomera (26 whales), northeast Tenerife (13 whales), and Gran Canaria (six whales), and three whales had centres of activity in three different areas Figure 6b). The most frequently seen animals seemed to share their range with "transient" animals, which were seen not only when associated with "residents" but also when in isolated groups (Figure S4). There were no significant differences in the ranges (Kernel 50\% and 95\% UD) between males and females (Mann-Whitney $\mathrm{U}$ test, $\mathrm{U}=1,334, \mathrm{p}=0.551, \mathrm{~N}=120 ; \mathrm{U}=$ $1,276, \mathrm{p}=0.349, \mathrm{~N}=120$, respectively).

\section{DISCUSSION}

SFPWs in the Canary Islands showed significant temporal and spatial variation in patterns of occurrence with higher encounter rates recorded during the warmer months and high variability in island-associated encounter rates. Residency patterns in the archipelago were characterized by a mixture of "residents", "transients", and "occasional" temporary migrants, in agreement with findings for other SFPW populations around oceanic islands (Alves et al., 2013; Mahaffy et al., 2015). "Resident" groups of whales that had ranging areas of limited size and that overlapped considerably were mostly located in southwest Tenerife and La Gomera. The majority (62\%) of whales, however, were seen no more than twice and in only one season (defined as "transients").

The inclusion of each individual SFPW in a resident or non-resident category is not definitive because categorization was based on resighting rates which are samples and may therefore change with additional data. However, the "transient" and "temporary migrant" categories that are based on few resightings are most susceptible to this; animals currently categorised as resident are unlikely to change category with additional data.

It is not known whether some animals occurring in the study area are part of a population that uses or moves through it only at certain times. Animals sighted only once could be "transients" passing through the archipelago, have ranges that barely overlap the study area, be behaviourally less likely to be captured, have died or permanently emigrated or simply not have been re-sighted during the study period in the area (Alves et al., 2013). The high percentage of "transients" recorded might also be a consequence of the large size of the study site $\left(109,000 \mathrm{~km}^{2}\right)$ that did not allow the whole area to be completely and homogeneously covered. Most of the northern windward areas of the islands were excluded, and most of the effort was concentrated in southern coastal leeward waters. 
This might have resulted in the failure to detect some high use areas, either extensions to identified areas or new areas.

Extending the study area to the northern windward areas might result in capturing new previously uncaptured whales, possibly lower the number of whales classified as "transients" and extend the resident distribution. However, long-distance movements for this species should be expected (Aguilar Soto et al., 2008; Sakai et al., 2011; Servidio, 2014), so the size of the study area alone is unlikely to account for the large number of transient whales identified during the study. Indeed, the individuals recaptured between Madeira and the Canary Islands $590.3 \mathrm{~km}$ apart (Servidio, 2014) appears not to be an isolated event (Alves et al., 2019)

The factors that influence residency patterns of pilot whales and their movements among the islands and archipelagos are poorly understood. They may not be determined by a single factor but instead could be a result of the combination of several and simultaneous variables (McLoughlin \& Ferguson, 2000), such as the availability and distribution of resources (food, mates, and shelter; e.g. Abend \& Smith, 1999; Alves et al., 2013; De Stephanis, García-Tíscar, et al., 2008).

Oceanic islands can be considered generators of biological patchiness (Barton et al., 2000). This and the highly dynamic oceanic ecosystem, in contrast to more productive coastal and inshore areas (Arístegui et al., 2006; Barton et al., 1998), might be responsible for attracting SFPWs from neighbouring ocean regions to the Canary Islands to use the area as a foraging ground on a temporary basis. Conversely, they may also force whales either to travel between familiar and already established feeding sites or to explore larger areas and to venture outside their typical range in search of new food patches, leading to between-island and more pelagic movements. At the same time, the presence of this species year-round, with individuals characterised by a high fidelity to the Canary Islands, indicates that some parts of the archipelago might also offer enough resources to hold a resident population of SFPW.

In the western part of the archipelago, the islands offer protection from the prevailing currents, whilst the effect of the anticyclonic gyre, the upwelling filaments and the general pattern of ocean currents increase nutrients and promote organism retention and thus potentially increase the base of the food web supporting increased biodiversity quite close to the coast (Arístegui et al., 2006; Arístegui et al., 1989; Arístegui et al., 1997; Hernández-León, Gomez, \& Arístegui, 2007). These deep, productive, and sheltered waters close to the coast thus make these areas especially suitable for raising calves and feeding able to support "resident" insular populations but also visiting "transients". Many movements of the "resident" animals seen in Tenerife were also observed 
outside their estimated core ranges, with multiple inter-island movements to and from La Gomera and, in some cases, Gran Canaria. Whales were observed to travel repeatedly back and forth between these areas, indicating that these movements were likely ranging rather than dispersal.

The eastern islands, conversely, which were visited almost exclusively by "transient" SFPWs in large groups, are characterised by wider continental shelves, unsheltered waters generally open to the effects of the main northerly currents and several mesoscale physical features. It can be speculated that these habitats, including Lanzarote and Fuerteventura, may provide only temporary or less abundant or available prey resources that cannot support resident populations and may therefore be visited infrequently.

Different ecological requirements may be responsible for differences in habitat use and for the development of different diving and feeding strategies (Aguilar Soto et al., 2008; Baird, Borsani, Hanson, \& Tyack, 2002; Baird et al., 2006; Watwood, Miller, Johnson, Madsen, \& Tyack, 2006). Species that are members of the same ecological guild with similar diets may use particular resources in different ways or, more generally, exploit more or fewer resource types, by having a wide or narrow niche range, respectively (generalists or specialists) (Whitehead, 2003), thereby avoiding competition for resources. Niche separation and geographic segregation have been proposed in beaked whale species with similar dietary preferences (MacLeod, Santos, \& Pierce, 2003). Differences in foraging tactics and therefore in targeted resources at depth have been hypothesised as explaining the spatial segregation of the resident populations of short-finned pilot whales in Tenerife and Blainville's beaked whales in El Hierro (Aguilar de Soto, 2006a). SFPWs seem to feed on prey with more muscle mass rather than on less mobile prey with lower individual caloric value, as do beaked whales (Aguilar de Soto, 2006b). In Tenerife, although there is a high cetacean biodiversity in terms of the number of species found, species other than SFPWs occur only occasionally or in confined areas (Carrillo et al., 2010; SECAC, unpubl data) with almost no overlap with the core range of SFPWs.

Ranging behaviour is believed to influence cetacean social structure by limiting the number of potential interactions of each individual to those animals that share analogous ranges (Lusseau et al., 2006). Even though southwest Tenerife represents the area of greatest usage for all the most frequently seen SFPW in the Canary Islands, the "residents" were here often observed (32\% of the sightings) interacting with "occasional" and "transient" individuals, which suggests that they might be sharing extensive areas of their ranges. 
460 SFPW social structure is believed to be characterised by long term, stable social bonds (Alves et al., 461 2013; Mahaffy et al., 2015). The similarity in ranging patterns of individuals within the resident groups and their multiple interactions may indicate that these individuals comprise a social community (individuals with long-term site fidelity, nearly all in association with each other; Urian, Hofmann, Wells, \& Read, 2009; Whitehead, 2008), but the hypothesis that the common ranges simply result from aggregative behaviour as a response to higher prey availability cannot be ruled out. Although it is impossible to determine if breeding actually takes place during these encounters in the southwest Tenerife, resident SFPWs do not seem to constitute a closed and isolated unit, because they often interact with other animals and share extensive areas of their ranges with nonresident whales. Rather, it seems more likely that there is genetic interchange among whales with different group residency patterns preventing genetic divergence of geographic-based populations, in accordance with results found in Madeira (Alves et al., 2013).

Seasonal fluctuation of group size has been described for both short- and long-finned pilot whales (Alves et al., 2013; Cañadas \& Sagarminaga, 2000; De Stephanis, Verborgh, et al., 2008; Felleman, Heimlich-Boran, \& Osborne, 1991), and can be related to breeding behaviour, with sub-groups regrouping to mate (De Stephanis, Verborgh, et al., 2008). Carrillo et al. (2010) identified Tenerife as an important calving ground for the SFPW, based on the year-round presence of neonates in the area, with a higher frequency between June and October. The seasons when larger group sizes were detected correspond to mating seasons observed in Tenerife by Heimlich-Boran (1993). In this study, in Tenerife a higher frequency of neonates in groups (83\%) was recorded during summer and autumn. The gestation period has been estimated for this species to last 14.9 months (Kasuya \& Marsh, 1984), so breeding likely occurs mostly during the warmer months, when a high proportion of "transient" and "occasional" whales enter the archipelago and mix with the resident population, forming larger groups of adults of both sexes. Although sex differentiation in this study was based only on qualitative assessment and not supported by genetic studies, observations showed no evidence that sex influenced movement patterns or core range size. In most cases, mixed sex groups, including groups with calves, travelled the greatest distances between the islands providing opportunities for animals associated with different islands to mix (at least among Tenerife, La Gomera and Gran Canaria). Thus, males would have ready access to potential mates and this may explain the lack of evidence for males moving more than females.

The southwestern waters of Tenerife, where most of the resident individuals spend most of their time and which results indicate are important for feeding and calving, is also the area with the greatest exposure to human activities that pose a potential risk to SFPWs. 
493 As a result of its climatic and oceanographic characteristics, with warm temperatures and calm and productive waters year-round (Arístegui et al., 1994; Barton et al., 2000), the southwestern coast of Tenerife has become a highly developed urban area. Large-scale coastal developments, a growing number of marinas and other coastal infrastructure have been direct consequences of the steadily increasing tourism to this area. Moreover, the majority of the artisanal fisheries of the island operates in the same waters as recreational activities and where boat and ferry traffic are concentrated. The high predictability of observing SFPW in this area has led to this species becoming the main target of a prospering whale-watching industry (in 2008, there were 37 vessels licensed, 625,000 visitors, generating 19.8 million euro of direct gross income; Elejabeita \& Urquiola, 2009). It is also one of the species most affected by ship-strikes (Arbelo, 2007; Carrillo \& Ritter, 2010; De Stephanis \& Urquiola, 2006), making the SFPW the species under most pressure from anthropogenic activity in the archipelago. The importance of southwestern Tenerife waters for resident SFPWs combined with the multiple and high pressure human activities there, makes this a priority area for conservation assessment. The social structure of this population and how this may affect its vulnerability is the subject of another study (Servidio et al, in prep), which will also provide important information for management bodies to take into account when considering mitigation strategies.

More widely, the new information presented here can be used to support a more complete assessment of the status of short-finned pilot whale population(s) throughout the entire Canary

511 Islands archipelago. Specifically, this study has established the first and necessary scientific basis 512 required for this species for criterion D1C4 (Range and Distribution pattern) established by OSPAR 513 (OSPAR, 2011) to design and implement an Action Plan with the aim of contributing to Good 514 Environmental Status (GES) of the marine habitat by 2020, as required by the Marine Strategy 515 Framework Directive (MSFD -Directive 2008/56/EC). In this context, the MISTIC SEAS I and II projects (11.0661/2015/712629/SUB/ENV.C2 and 11.0661/2017/750679/SUB/ENV.C2), initiated in 2015 in the Macaronesia Northeast Atlantic sub-region, had the objective to establish a common roadmap to monitor the status of marine mammals, sea turtles, and seabirds and to obtain baseline information for better coordination and implementation of the MSFD. In the Canary Islands the short-finned pilot whales of Tenerife and La Gomera were treated as a management unit (animals of a particular species in a geographical area to which management of human activities is applied) within the archipelago, and were considered a very good potential indicator of GES because of the long and comprehensive data series generated by this study. As a result of the new information on the spatial and temporal distribution of "transients" and island-associated animals highlighted by this study, two Management Units for short-finned pilot whales were identified in the Canary Islands, namely: I - all short-finned pilot whales using coastal waters of the Canary archipelago 
527 (transients, occasional visitors and island-associated animals); II - island-associated animals of

528 Tenerife and La Gomera. Thus, it will be possible to monitor the range and distribution of transients

529 using the area as well as island-associated animals, possibly better focus and differentiate pressures

530 impacting the two MUs, and understand the contribution of local factors as drivers of changes in

531 site fidelity.

532 We conclude that different populations of pilot whales seem to be simultaneously present in the

533 Canary Islands. There is a SFPW resident population with a strong site-fidelity to multiple core

534 areas that are characterised by sufficient resources to support its year-round presence. Conversely,

535 there are "transient" animals which, probably driven by inter- and intraspecific competition may

536 travel long distances and may use the archipelago as part of a larger range, within which areas are

537 used temporarily for resting-mating-feeding. The resident population does not seem to be isolated;

538 rather "resident" individuals share ranges and come into contact with other animals from within and

539 outside the archipelago.

540 Further studies supported by genetic analysis and telemetry studies are needed to verify the

541 differences (genetic and behavioural) among individuals with different residency patterns in the

542 Canary Islands. This additional information would strengthen the scientific basis for conservation

543 assessments of SFPWs and allow any management actions to be most effectively focussed. 


\section{COMPLIANCE WITH ETHICAL STANDARDS}

546 Conflict of interest: The authors declare they have no conflict of interest.

547 Ethical approval: All applicable international, national, and/or institutional guidelines for the care 548 and use of animals were followed and all necessary approvals were obtained. The official research 549 permission was given by the Ministry of Agriculture, Food and Environment.

\section{ACKNOWLEDGEMENTS:}

551 For helpful comments and suggestions, we thank Silvana Neves, Erika Urquiola, Antonio 552 Fernández, Manuel Arbelo, Ricardo Antunes, Luis Freitas, Filipe Alves, Renaud de Stephanis and 553 two anonymous reviewers. Thanks to Nuria Varo, Cristina Lorenzo, Rocío Díaz Bacallado,

554 Mercedes Reyes, María del Mar Cañados, Marisa Tejedor, Leire Ruiz, Sonía García, Saioa 555 Talavera, Bernd Braderlau, Silvia Hildebrant, Arquímedes Bermúdez, María Ovando, and José 556 Antonio Vázquez for their field work assistance. We are also grateful to all the volunteers who 557 helped us. The field work was conducted by SECAC and was co-funded by the Canary Government 558 (Consejería de Política Territorial, Sostenibilidad y Seguridad), the Spanish Government 559 (Fundación Biodiversidad and Ministerio de Medio Ambiente, Medio Rural y Marino), Fundación 560 La Caixa, and by a number of international projects funded by EU programmes MACETUS 561 (FEDER/INTERREG III-B MAC/4.2/M10), EMECETUS (FEDER/INTERREG III-B 562 05/MAC/4.2/M10), LIFE (LIFE03NAT0062), INDEMARES LIFE+ (LIFE07/NAT/E/00732). 


\section{REFERENCES}

Abend, A. G., \& Smith, T. D. (1999). Review of distribution of the long-finned pilot whale (Globicephala melas) in the North Atlantic and Mediterranean: US Department of Commerce, National Oceanic and Atmospheric Administration ....

Adams, L., \& Davis, S. D. (1967). The internal anatomy of home range. Journal of mammalogy, 48(4), 529536.

Aguilar de Soto, N. (2006a). Acoustic and diving behaviour of the short finned pilot whale (Globicephala macrorhynchus) and Blainville's beaked whale (Mesoplodon densirostris) in the Canary Islands. Implications on the effects ofman-made noise and boat collisions. (Ph.D. Thesis Doctor of Philosophy), University of La Laguna, La Laguna, España.

Aguilar de Soto, N. (2006b). Acoustic and diving behaviour of the short finned pilot whale (Globicephala macrorhynchus) and Blainville's beaked whale (Mesoplodon densirostris) in the Canary Islands. Implications on the effects of man-made noise and boat collisions. Ph. D. thesis, Universidad de La Laguna, La Laguna, Spain.

Aguilar Soto, N., Johnson, M. P., Madsen, P. T., Díaz, F., Domínguez, I., Brito, A., \& Tyack, P. (2008). Cheetahs of the deep sea: deep foraging sprints in short-finned pilot whales off Tenerife (Canary Islands). Journal of Animal Ecology, 77(5), 936-947.

Alves, F., Alessandrini, A., Servidio, A., Mendonça, A. S., Hartman, K. L., Prieto, R., . . Santos, R. (2019). Complex biogeographical patterns support an ecological connectivity network of a large marine predator in the north-east Atlantic. Diversity and Distributions, 25(2), 269-284.

Alves, F., Quérouil, S., Dinis, A., Nicolau, C., Ribeiro, C., Freitas, L., . . Fortuna, C. (2013). Population structure of short-finned pilot whales in the oceanic archipelago of Madeira based on photoidentification and genetic analyses: implications for conservation. Aquatic Conservation: Marine and freshwater ecosystems, 23(5), 758-776.

Arbelo, M. (2007). Patología y causas de la muerte de los cetáceos varados en las Islas Canarias (19992005). Ph. D. Doctoral thesis, University of Las Palmas de Gran Canaria, Las Palmas ....

Arístegui, J., Alvarez-Salgado, X., Barton, E., Figueiras, F., Hernandez-Leon, S., Roy, C., \& Santos, A. (2006). Oceanography and fisheries of the Canary Current/Iberian region of the Eastern North Atlantic (18a, E). The global coastal ocean: interdisciplinary regional studies and syntheses, 14, 879. 
Arístegui, J., Hernández-León, S., Gómez, M., Medina, L., Ojeda, A., \& Torres, S. (1989). Influence of the north trade winds on the biomass and production of neritic plankton around Gran Canaria Island. Sci. Mar., 53(2), 223-229.

Arístegui, J., Sangrá, P., Hernández-León, S., Cantón, M., Hernández-Guerra, A., \& Kerling, J. (1994). Island-induced eddies in the Canary Islands. Deep Sea Research Part I: Oceanographic Research Papers, 41(10), 1509-1525.

Arístegui, J., Tett, P., Hernández-Guerra, A., Basterretxea, G., Montero, M. F., Wild, K., . . García-Braun, J. (1997). The influence of island-generated eddies on chlorophyll distribution: a study of mesoscale variation around Gran Canaria. Deep Sea Research Part I: Oceanographic Research Papers, 44(1), $71-96$

Arnbom, T. (1987). Individual identification of sperm whales. Report of the International Whaling Commission, 37(20), 1-204.

Baird, R. W., Borsani, J. F., Hanson, M. B., \& Tyack, P. L. (2002). Diving and night-time behavior of longfinned pilot whales in the Ligurian Sea. Marine Ecology Progress Series, 237, 301-305.

Baird, R. W., Gorgone, A. M., McSweeney, D. J., Webster, D. L., Salden, D. R., Deakos, M. H., . . . Mahaffy, S. D. (2008). False killer whales (Pseudorca crassidens) around the main Hawaiian Islands: Long-term site fidelity, inter-island movements, and association patterns. Marine Mammal Science, 24(3), 591-612.

Baird, R. W., Schorr, G. S., Webster, D. L., Mahaffy, S. D., Douglas, A. B., Gorgone, A. M., \& McSweeney, D. J. (2006). A survey for odontocete cetaceans off Kaua'i and Ni'ihau, Hawai'i, during October and November 2005: evidence for population structure and site fidelity: CASCADIA RESEARCH COLLECTIVE OLYMPIA WA.

Baird, R. W., Webster, D. L., Mahaffy, S. D., McSweeney, D. J., Schorr, G. S., \& Ligon, A. D. (2008). Site fidelity and association patterns in a deep-water dolphin: Rough-toothed dolphins (Steno bredanensis) in the Hawaiian Archipelago. Marine Mammal Science, 24(3), 535-553.

Barton, E., Arıstegui, J., Tett, P., Cantón, M., Garcı-Braun, J., Hernández-León, S., . . Ballesteros, S. (1998). The transition zone of the Canary Current upwelling region. Progress in Oceanography, $41(4), 455-504$.

Barton, E., Basterretxea, G., Flament, P., Mitchelson-Jacob, E. G., Jones, B., Arístegui, J., \& Herrera, F. (2000). Lee region of gran canaria. Journal of Geophysical Research: Oceans, 105(C7), 1717317193. 
Brown, J. L., \& Orians, G. H. (1970). Spacing patterns in mobile animals. Annual review of ecology and systematics, 1(1), 239-262.

Burnham, K. P., \& Anderson, D. R. (2003). Model selection and multimodel inference: a practical information-theoretic approach: Springer Science \& Business Media.

Burt, W. H. (1943). Territoriality and home range concepts as applied to mammals. Journal of mammalogy, 24(3), 346-352.

Cañadas, A., \& Sagarminaga, R. (2000). The northeastern Alboran Sea, an important breeding and feeding ground for the long-finned pilot whale (Globicephala melas) in the Mediterranean Sea. Marine Mammal Science, 16(3), 513-529.

Carracedo, J. (2001). Volcanismo reciente y riesgo volcánico. Naturaleza de las Islas Canarias: ecologıa y conservación. Santa Cruz de Tenerife, Turquesa, 65-76.

Carrillo, M., Pérez-Vallazza, C., \& Álvarez-Vázquez, R. (2010). Cetacean diversity and distribution off Tenerife (Canary Islands). Marine Biodiversity Records, 3.

Carrillo, M., \& Ritter, F. (2010). Increasing numbers of ship strikes in the Canary Islands: proposals for immediate action to reduce risk of vessel-whale collisions. Journal of cetacean research and management, 11(2), 131-138.

Clutton-Brock, T. (1975). Ranging behaviour of red colobus (Colobus badius tephrosceles) in the Gombe National Park. Animal Behaviour, 23, 706-722.

Clutton-Brock, T., \& Albon, S. (1985). Competition and population regulation in social mammals.

Clutton-Brock, T. H. (1989). Review lecture: mammalian mating systems. Proc. R. Soc. Lond. B, 236(1285), 339-372.

Crook, J. H., Ellis, J., \& Goss-Custard, J. (1976). Mammalian social systems: structure and function. Animal Behaviour, 24(2), 261-274.

Davies, N., \& Houston, A. (1994). Territory economics. Behavioural Ecology. An Evolutionary Approach, 148-169.

De Stephanis, R., García-Tíscar, S., Verborgh, P., Esteban-Pavo, R., Pérez, S., Minvielle-Sébastia, L., \& Guinet, C. (2008). Diet of the social groups of long-finned pilot whales (Globicephala melas) in the Strait of Gibraltar. Marine Biology, 154(4), 603-612. 
De Stephanis, R., \& Urquiola, E. (2006). Collisions between ships and cetaceans in Spain. Int. Whal. Commn. Scientific Committee SC/58/BC5.

De Stephanis, R., Verborgh, P., Pérez, S., Esteban, R., Minvielle-Sebastia, L., \& Guinet, C. (2008). Longterm social structure of long-finned pilot whales (Globicephala melas) in the Strait of Gibraltar. Acta Ethologica, 11(2), 81.

Dixon, K. R., \& Chapman, J. A. (1980). Harmonic mean measure of animal activity areas. Ecology, 61(5), 1040-1044.

Dufault, S., \& Whitehead, H. (1993). Assessing the stock identity of sperm whales in the eastern equatorial Pacific. Reports of the International Whaling Commission, 43, 469-475.

Dufault, S., \& Whitehead, H. (1995). An assessment of changes with time in the marking patterns used for photoidentification of individual sperm whales, Physeter macrocephalus. Marine Mammal Science, 11(3), 335-343.

Elejabeita, C., \& Urquiola, E. (2009). Whale watching in the Canary Islands. International Whaling Commission.

Emlen, S. T., \& Oring, L. W. (1977). Ecology, sexual selection, and the evolution of mating systems. Science, 197(4300), 215-223.

Escorza, S., Heimlich-Boran, S., \& Heimlich-Boran, J. (1992). Bottle-nosed Dolphins off the Canary Islands. European Research on Cetaceans, 6, 117-120.

Felleman, F. L., Heimlich-Boran, J. R., \& Osborne, R. W. (1991). The feeding ecology of killer whales (Orcinus orca) in the Pacific Northwest. Dolphin societies: Discoveries and puzzles, 113-147.

Habel, J. C., Hillen, J., Schmitt, T., \& Fischer, C. (2016). Restricted movements and high site fidelity in three East African cloud-forest birds. Journal of Tropical Ecology, 32(1), 83-87.

Harestad, A. S., \& Bunnel, F. (1979). Home Range and Body Weight--A Reevaluation. Ecology, 60(2), 389402.

Hastie, G. D., Barton, T. R., Grellier, K., Hammond, P. S., SwIFT, R. J., Thompson, P. M., \& Wilson, B. (2003). Distribution of small cetaceans within a candidate Special Area of Conservation; implications for management. Journal of cetacean research and management, 5(3), 261-266.

Heimlich-Boran, J. R. (1993). Social organisation of the short-finned pilot whale, Globicephala macrorhynchus, with special reference to the comparative social ecology of delphinids. University of Cambridge. 
Hernández-León, S., Gomez, M., \& Arístegui, J. (2007). Mesozooplankton in the Canary Current System: The coastal-ocean transition zone. Progress in Oceanography, 74(2-3), 397-421.

Hooge, P., \& Eichenlaub, B. (1997). Animal movement extension to arcview. ver. 1.1. Alaska Science Center-Biological Science Office. US Geological Survey, Anchorage, AK, USA.

Hooker, S. K., Whitehead, H., \& Gowans, S. (1999). Marine protected area design and the spatial and temporal distribution of cetaceans in a submarine canyon. Conservation Biology, 13(3), 592-602.

Hunt, T. N., Bejder, L., Allen, S. J., Rankin, R. W., Hanf, D., \& Parra, G. J. (2017). Demographic characteristics of Australian humpback dolphins reveal important habitat toward the southwestern limit of their range. Endangered Species Research, 32, 71-88.

Inglis, J. M., Hood, R. E., Brown, B. A., \& DeYoung, C. A. (1979). Home range of white-tailed deer in Texas coastal prairie brushland. Journal of mammalogy, 60(2), 377-389.

Ingram, S. N., \& Rogan, E. (2002). Identifying critical areas and habitat preferences of bottlenose dolphins Tursiops truncatus. Marine Ecology Progress Series, 244, 247-255.

Karczmarski, L., Würsig, B., Gailey, G., Larson, K. W., \& Vanderlip, C. (2005). Spinner dolphins in a remote Hawaiian atoll: social grouping and population structure. Behavioral Ecology, 16(4), 675685.

Kasuya, T., \& Marsh, H. (1984). Life history and reproductive biology of the short-finned pilot whale, Globicephala macrorhynchus, off the Pacific coast of Japan. Report of the International Whaling Commission, Special, 6, 259-310.

Kernohan, B. J., Gitzen, R. A., \& Millspaugh, J. J. (2001). Analysis of animal space use and movements Radio tracking and animal populations (pp. 125-166): Elsevier.

King, S. (2002). Home range and habitat use of free-ranging Przewalski horses at Hustai National Park, Mongolia. Applied Animal Behaviour Science, 78(2-4), 103-113.

Lusseau, D., Wilson, B., Hammond, P. S., Grellier, K., Durban, J. W., Parsons, K. M., . . Thompson, P. M. (2006). Quantifying the influence of sociality on population structure in bottlenose dolphins. Journal of Animal Ecology, 75(1), 14-24.

MacLeod, C. D., Santos, M., \& Pierce, G. J. (2003). Review of data on diets of beaked whales: evidence of niche separation and geographic segregation. Journal of the Marine Biological Association of the United Kingdom, 83(3), 651-665. 
Mahaffy, S. D., Baird, R. W., McSweeney, D. J., Webster, D. L., \& Schorr, G. S. (2015). High site fidelity, strong associations, and long-term bonds: Short-finned pilot whales off the island of Hawai ' $\mathrm{i}$. Marine Mammal Science, 31(4), 1427-1451.

McGuire, T. L., \& Henningsen, T. (2007). Movement patterns and site fidelity of river dolphins (Inia geoffrensis and Sotalia fluviatilis) in the Peruvian Amazon as determined by photo-identification. Aquatic Mammals, 33(3), 359.

McLoughlin, P. D., \& Ferguson, S. H. (2000). A hierarchical pattern of limiting factors helps explain variation in home range size. Ecoscience, 7(2), 123-130.

McNab, B. K. (1963). Bioenergetics and the determination of home range size. The American Naturalist, 97(894), 133-140.

McSweeney, D. J., Baird, R. W., Mahaffy, S. D., Webster, D. L., \& Schorr, G. S. (2009). Site fidelity and association patterns of a rare species: pygmy killer whales (Feresa attenuata) in the main Hawaiian Islands. Marine Mammal Science, 25(3), 557-572.

Milinski, M., \& Parker, G. A. (1991). Competition for resources. Behavioural ecology: an evolutionary approach, 3, 137-168.

Montero, R., \& Arechavaleta, M. (1996). Distribution patterns: relationships between depths, sea surface temperature, and habitat use of short-finned pilot whales south-west of Tenerife. European Research on Cetaceans, 10, 193-198.

Oremus, M., Gales, R., Dalebout, M. L., Funahashi, N., Endo, T., Kage, T., . . Baker, S. C. (2009). Worldwide mitochondrial DNA diversity and phylogeography of pilot whales (Globicephala spp.). Biological Journal of the Linnean Society, 98(4), 729-744.

OSPAR. (2011). Report of the OSPAR workshop on MSFD biodiversity descriptors: comparison of targets and associated indicators. . OSPAR Commission Publication, 575, 56 pp.

Ostfeld, R. S. (1990). The ecology of territoriality in small mammals. Trends in Ecology \& Evolution, 5(12), 411-415.

Parra, G. J., Corkeron, P. J., \& Marsh, H. (2006). Population sizes, site fidelity and residence patterns of Australian snubfin and Indo-Pacific humpback dolphins: Implications for conservation. Biological Conservation, 129(2), 167-180.

Pérez-Gil, M., Martín, V., Tejedor, M., Servidio, A., Neves, S., Pérez-Gil, E., . . Brederlau, B. (2011). Agonistic behaviour of Risso's dolphins towards sperm whales in the SW of Fuerteventura, Canary 
Islands, with a discussion on trophic competence in cetaceans. European Cetacean Society, Cambridge.

Sakai, M., Aoki, K., Sato, K., Amano, M., Baird, R. W., Webster, D. L., . . Miyazaki, N. (2011). Swim speed and acceleration measurements of short-finned pilot whales (Globicephala macrorhynchus) in Hawai'i. Mammal study, 36(1), 55-59.

Scott, M. D., Wells, R. S., Irvine, A. B., \& Mate, B. R. (1989). Tagging and marking studies on small cetaceans The bottlenose dolphin (pp. 489-514): Elsevier.

Schoener, T. W. (1968). Sizes of feeding territories among birds. Ecology, 49(1), 123-141.

Schoener, T. W. (1981). An empirically based estimate of home range. Theoretical Population Biology, 20(3), 281-325.

Servidio, A. (2014). Distribution, social structure and habitat use of short-finned pilot whale, Globicephala macrorhynchus, in the Canary Islands. University of St Andrews.

Silva, M. A., Prieto, R., Magalhães, S., Seabra, M. I., Santos, R. S., \& Hammond, P. S. (2008). Ranging patterns of bottlenose dolphins living in oceanic waters: implications for population structure. Marine Biology, 156(2), 179.

Swihart, R. K., \& Slade, N. A. (1985). Influence of sampling interval on estimates of home-range size. The Journal of Wildlife Management, 1019-1025.

Switzer, P. V. (1993). Site fidelity in predictable and unpredictable habitats. Evolutionary Ecology, 7(6), 533-555.

Thorne, L. H., Foley, H. J., Baird, R. W., Webster, D. L., Swaim, Z. T., \& Read, A. J. (2017). Movement and foraging behavior of short-finned pilot whales in the Mid-Atlantic Bight: importance of bathymetric features and implications for management. Marine Ecology Progress Series, 584, 245-257.

Tucker, M. A., Ord, T. J., \& Rogers, T. L. (2014). Evolutionary predictors of mammalian home range size: body mass, diet and the environment. Global Ecology and Biogeography, 23(10), 1105-1114.

Urian, K. W., Hofmann, S., Wells, R. S., \& Read, A. J. (2009). Fine-scale population structure of bottlenose dolphins (Tursiops truncatus) in Tampa Bay, Florida. Marine Mammal Science, 25(3), 619-638.

Van Cise, A. M., Morin, P. A., Baird, R. W., Lang, A. R., Robertson, K. M., Chivers, S. J., . . Martien, K. K. (2016). Redrawing the map: mt DNA provides new insight into the distribution and diversity of short-finned pilot whales in the Pacific Ocean. Marine Mammal Science, 32(4), 1177-1199. 
Watwood, S. L., Miller, P. J., Johnson, M., Madsen, P. T., \& Tyack, P. L. (2006). Deep-diving foraging behaviour of sperm whales (Physeter macrocephalus). Journal of Animal Ecology, 75(3), 814-825.

White, G. C., \& Garrott, R. A. (2012). Analysis of wildlife radio-tracking data: Elsevier.

Whitehead, H. (2001). Analysis of animal movement using opportunistic individual identifications: application to sperm whales. Ecology, 82(5), 1417-1432.

Whitehead, H. (2003). Sperm whales: social evolution in the ocean: University of Chicago press.

Whitehead, H. (2008). Analyzing animal societies: quantitative methods for vertebrate social analysis: University of Chicago Press.

Whitehead, H. (2009). SOCPROG programs: analysing animal social structures. Behavioral Ecology and Sociobiology, 63(5), 765-778.

Whitehead, H., \& Waters, S. (1990). Social organization and population structure of sperm whales off the Galapagos Islands, Ecuador (1985 and 1987). Rep. Int. Whal. Comm. Spec. Issue(12), 249-257.

Wilson, B., Thompson, P., \& Hammond, P. (1997). Habitat use by bottlenose dolphins: seasonal distribution and stratified movement patterns in the Moray Firth, Scotland. Journal of Applied Ecology, 13651374.

Williams, T. M. (1999). The evolution of cost efficient swimming in marine mammals: limits to energetic optimization. Philosophical Transactions of the Royal Society of London B: Biological Sciences, 354(1380), 193-201.

Williams, T. M., Friedl, W., \& Haun, J. (1993). The physiology of bottlenose dolphins (Tursiops truncatus): heart rate, metabolic rate and plasma lactate concentration during exercise. Journal of Experimental Biology, 179(1), 31-46.

Worton, B. (1987). A review of models of home range for animal movement. Ecological Modelling, 38(3-4), 277-298.

Worton, B. J. (1989). Kernel methods for estimating the utilization distribution in home-range studies. Ecology, 70(1), 164-168.

Würsig, B., \& Jefferson, T. A. (1990). Methods of photo-identification for small cetaceans. Use of PhotoIdentification and Other Techniques to Estimate Population Parameters. Report of the International Whaling Commission, Special Issue, 12, 43-52. 
799 Würsig, B., \& Jefferson, T. A. (1990). Methods of photoidentification for small cetaceans. Rep. Int. Whal. Commn.(Spec. Iss. 12), 43-52.

801 Würsig, B., \& Würsig, M. (1977). The photographic determination of group size, composition, and stability 802 of coastal porpoises (Tursiops truncatus). Science, 198(4318), 775-756.

803

Zanardo, N., Parra, G. J., \& Möller, L. M. (2016). Site fidelity, residency, and abundance of bottlenose 804 dolphins (Tursiops sp.) in Adelaide's coastal waters, South Australia. Marine Mammal Science, 805 32(4), 1381-1401. 
806 807

808

809

810

811

812

813

814

Table 3. Number of SFPWs in different residency categories seen in the whole archipelago (top row) and the number in each category seen around each island. Individuals in each category may be included in more than one island because of movement between islands.

\section{Island}

Core Resident Resident Occasional Transient Tot Ind

\begin{tabular}{lccccc}
\hline Canary Archipelago & $\mathbf{5 0}$ & $\mathbf{2 5 5}$ & $\mathbf{1 5 6}$ & $\mathbf{7 8 0}$ & $\mathbf{1 , 2 4 1}$ \\
\hline Tenerife & 50 & 246 & 128 & 287 & 711 \\
La Gomera & 14 & 88 & 56 & 100 & 258 \\
Lanzarote Fuerteventura & 0 & 0 & 10 & 263 & 273 \\
Gran Canaria & 3 & 22 & 14 & 138 & 177 \\
\hline
\end{tabular}

\begin{tabular}{lllllll}
\hline Island & Total & $\mathbf{A}$ & Indet & $\mathbf{J}$ & $\mathbf{C}$ & $\mathbf{N}$ \\
\hline Tenerife & 760 & 588 & 123 & 35 & 12 & 2 \\
La Gomera & 271 & 212 & 46 & 11 & 2 & 0 \\
Lanzarote-Fuerteventura & 282 & 161 & 112 & 7 & 2 & 0 \\
Gran Canaria & 190 & 146 & 31 & 9 & 3 & 1 \\
La Palma & 10 & 9 & 1 & 0 & 0 & 0 \\
\hline Total & 1,310 & 952 & 289 & 57 & 9 & 3 \\
\hline
\end{tabular}

\begin{tabular}{|c|c|c|c|}
\hline $\begin{array}{l}\text { On effort } \\
\text { km }\end{array}$ & Hr:min & $\begin{array}{l}\text { Sightings } \\
\text { on effort }\end{array}$ & off effort \\
\hline $29,529.86$ & $2,278: 41$ & 27 & 25 \\
\hline $10,145.68$ & 694:11 & 14 & 12 \\
\hline $9,976.02$ & $819: 40$ & 621 & 238 \\
\hline $9,853.16$ & $776: 40$ & 69 & 38 \\
\hline $8,190.53$ & $648: 46$ & 23 & 10 \\
\hline $2,084.02$ & $146: 10$ & 3 & 1 \\
\hline 841.10 & $72: 47$ & 0 & 0 \\
\hline $70,620.37$ & $5,436: 55$ & 757 & 324 \\
\hline
\end{tabular}

Table 2 Photo-identified SFPWs: picture quality 3 and 4; distinctiveness 3 and 4. Age classes: $\mathrm{A}=$ adults, Indet=indeterminates, $\mathrm{J}=$ juveniles, $\mathrm{C}=$ calves; and $\mathrm{N}=$ neonates 
816 Table 4 Diagnostics and estimated parameters for the best fitting models of LIRs applied to 817 all individual SFPWs identified in the Canary Islands (1999-2012), and in southwestern 818 Tenerife (2004-2009). Models were also applied to Tenerife and La Gomera to test how 819 SFPWs move between these two islands. $t d=$ time lag $(\boldsymbol{\tau}) ; \mathrm{a} 1, \mathrm{a} 2, \mathrm{a} 3=$ parameters of the 820 models. Values inside the brackets indicate the standard errors of the parameters calculated 821 using bootstrap replications

822

\begin{tabular}{|c|c|c|c|c|c|}
\hline \multirow{2}{*}{ Dataset } & \multirow{2}{*}{ Model } & & \multicolumn{3}{|c|}{ Parameters } \\
\hline & & & a1 & $\mathbf{a} 2$ & a3 \\
\hline $\begin{array}{l}\text { Canary } \\
\text { Islands }\end{array}$ & $\begin{array}{l}\text { Emigrati } \\
\text { on+ } \\
\text { Re- } \\
\text { immigrati } \\
\text { on }\end{array}$ & $\begin{array}{l}(1 / \mathrm{a} 1) *((1 / \mathrm{a} 3)+(1 / \mathrm{a} 2) * \\
\exp ((1 / \mathrm{a} 3+1 / \mathrm{a} 2) * \mathrm{td})) \\
/(1 / \mathrm{a} 3+1 / \mathrm{a} 2)\end{array}$ & $\begin{array}{l}253.84 \\
(9.93)\end{array}$ & $\begin{array}{l}530.96 \\
(23.82)\end{array}$ & $\begin{array}{l}4086.95 \\
(941.43)\end{array}$ \\
\hline $\begin{array}{l}\text { Southwest } \\
\text { Tenerife }\end{array}$ & $\begin{array}{l}\text { Emigrati } \\
\text { on/ }\end{array}$ & $\mathrm{a} 2 * \exp (-\mathrm{a} 1 * \mathrm{td})$ & $\begin{array}{l}0.0004808 \\
(7.1123 \mathrm{e}- \\
005)\end{array}$ & $\begin{array}{l}0.00358 \\
(0.00019 \\
)\end{array}$ & \\
\hline & & $(1 / \mathrm{a} 1)^{*} \exp (-\mathrm{td} / \mathrm{a} 2)$ & $\begin{array}{l}279.45 \\
(14.47)\end{array}$ & $\begin{array}{l}2048.60 \\
(268.28)\end{array}$ & \\
\hline
\end{tabular}

\section{From}

$\begin{array}{llll}\text { Tenerife } & \text { Fully } & \text { 1/a } 1 & 2718.52 \\ \text { to La } & \text { Mixed } & & (361.05)\end{array}$

\section{Gomera}

\section{From La}

$\begin{array}{llll}\text { Gomera } & \text { Fully } & 1 / \mathrm{a} 1 & 1686.18 \\ \text { to } & \text { Mixed } & & (221.54)\end{array}$

\section{Tenerife}




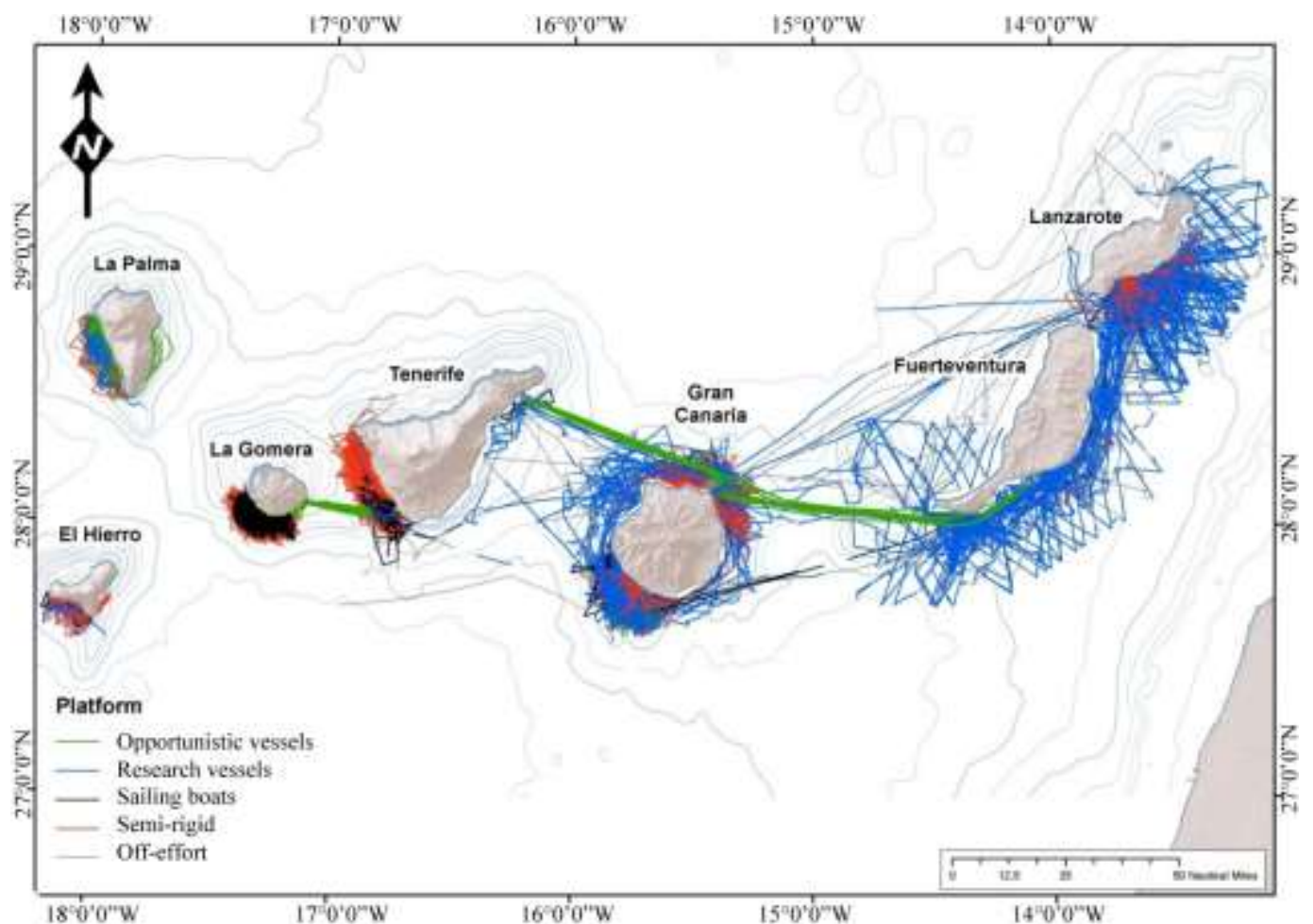

826 Fig 1 Transects surveyed (1999 - 2012) on board different vessel types: semi-rigid inflatable boats (red), dedicated motor boats (blue), sailing boats (black), and opportunist vessels such as whale-watching boats and ferries (green). Off-effort track-lines are indicated in grey.

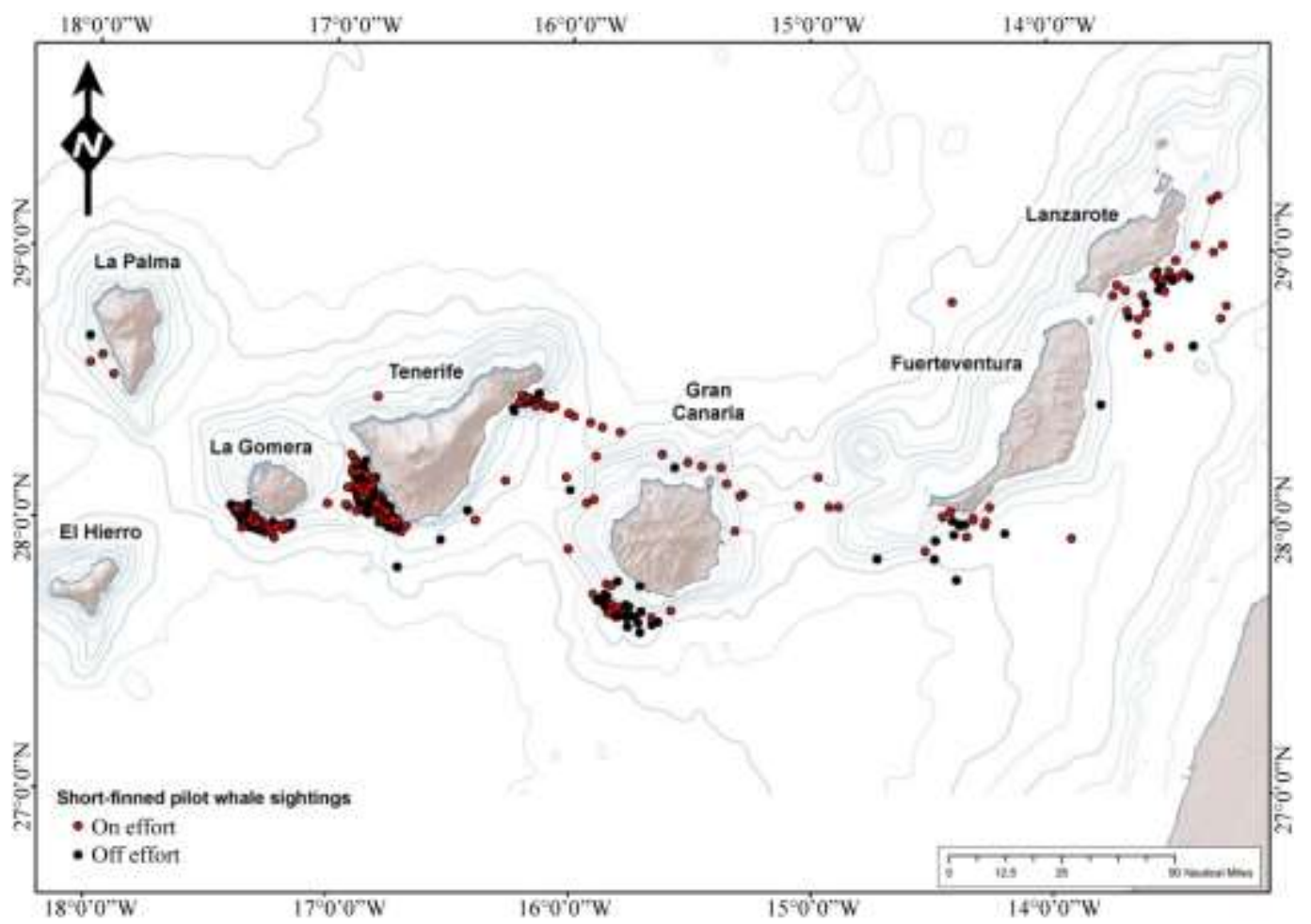

831 Fig 2 Short-finned pilot whale (SFPW, Globicephala macrorhynchus) sightings (1999-2012) 
833

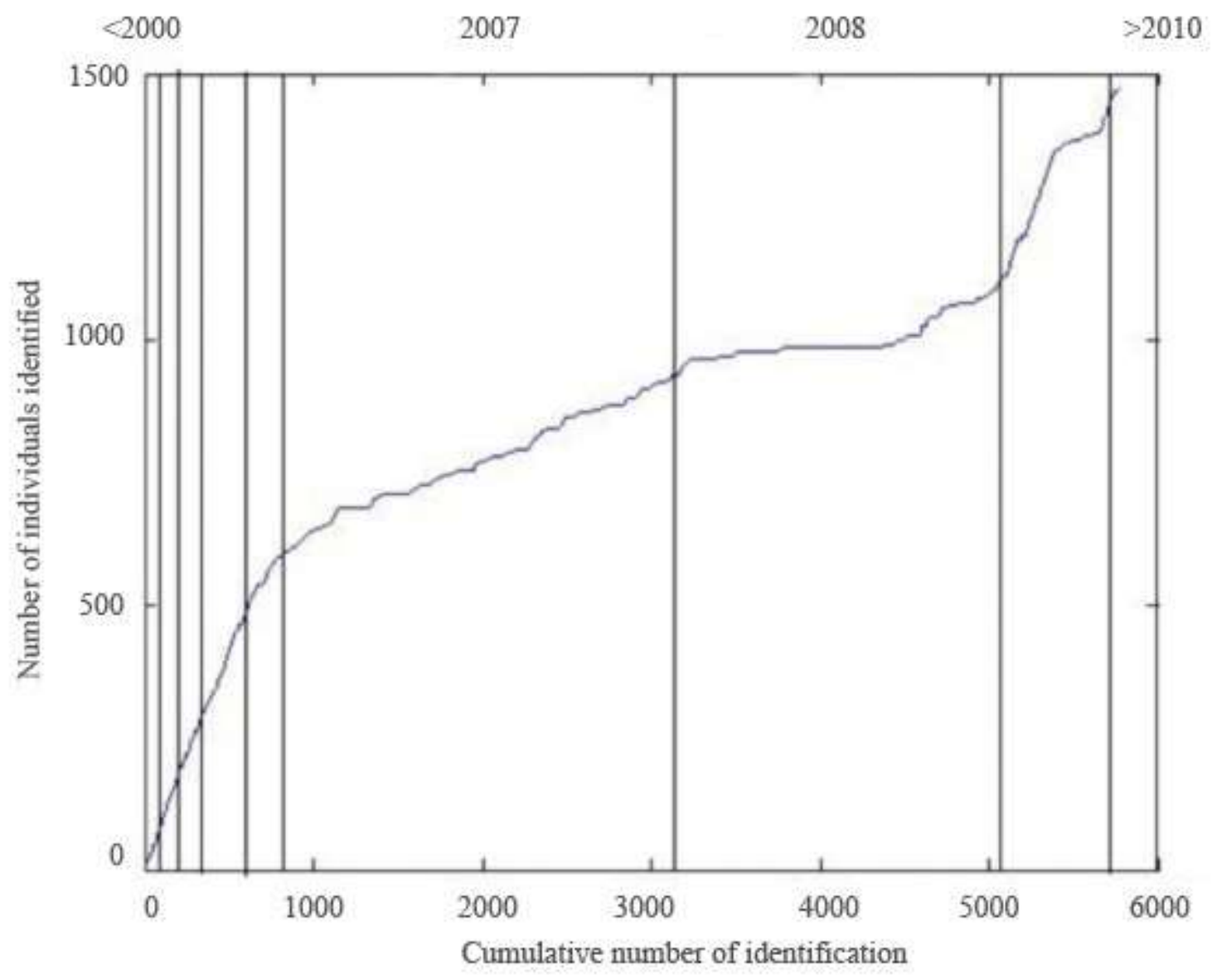

834

835 Fig 3 Discovery curve showing the number of new well-marked SFPWs identified each day.

836 Vertical lines divide years

837

838 


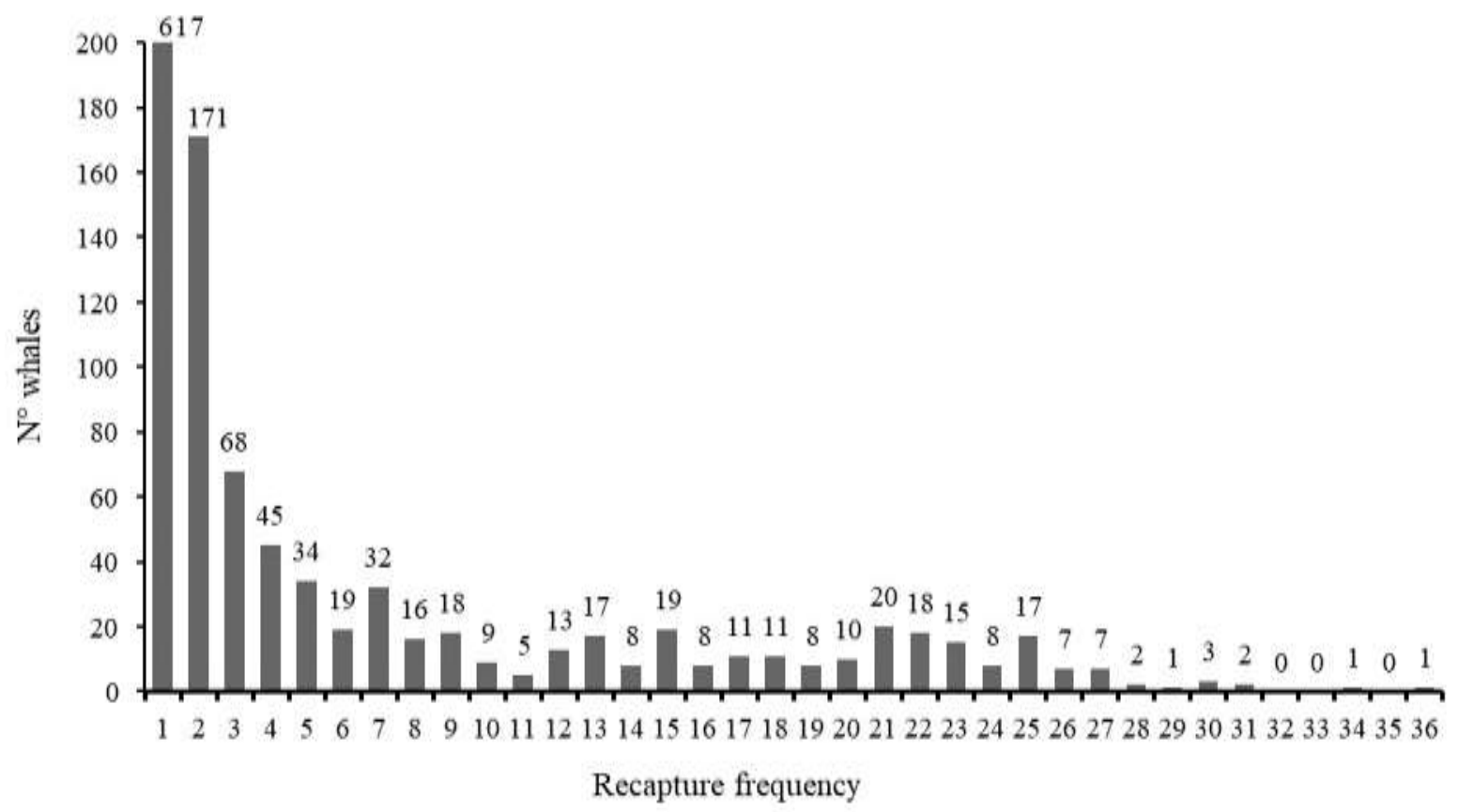

840 Fig 4 Frequency histogram of the number of times that uniquely marked SFPWs were 841 captured in the Canary Islands

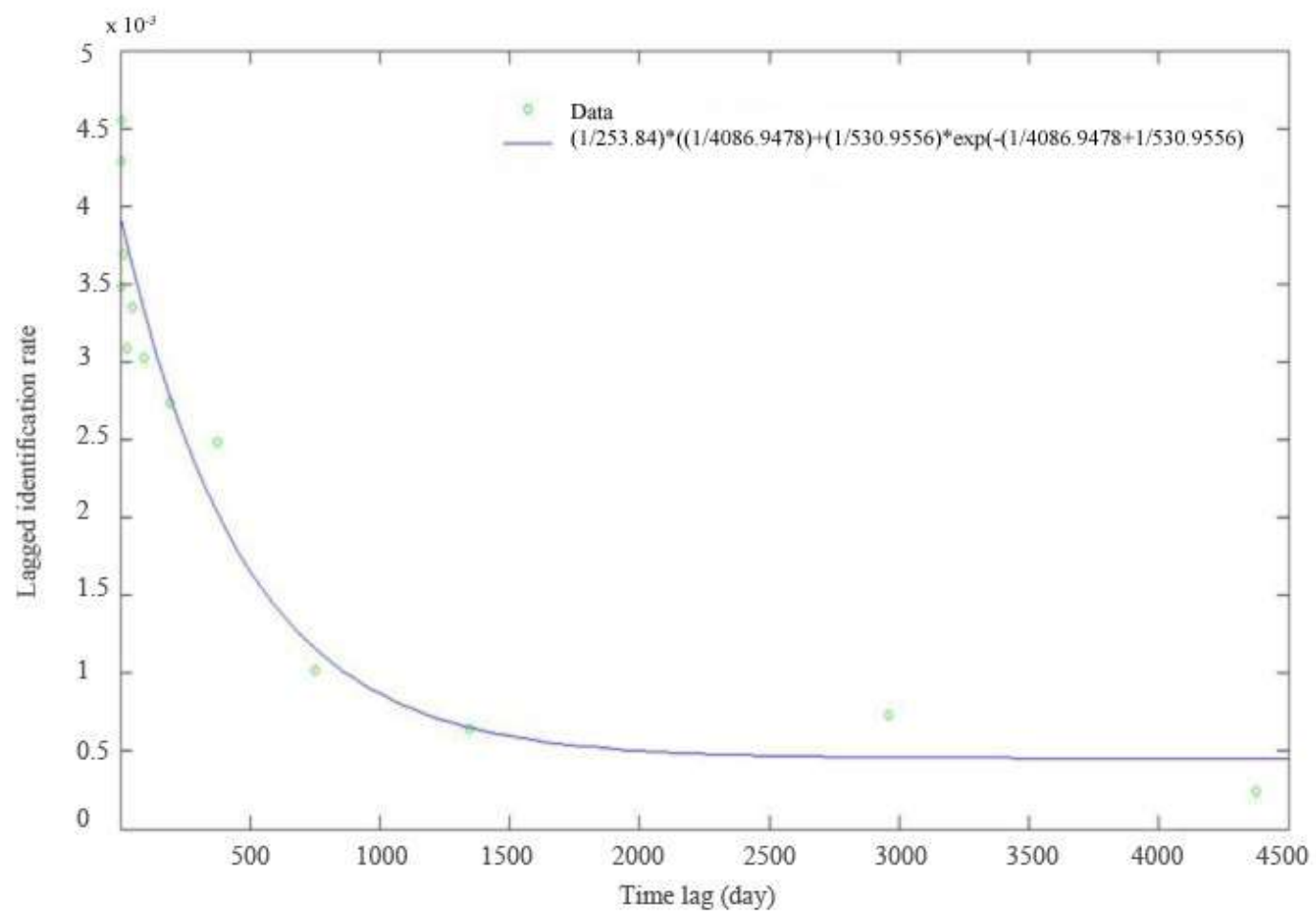

844 Fig 5 LIRs for all individual SFPWs identified. Data points are represented as circles and the 845 best fitting model (Emigration + Re-immigration) is displayed as a line 


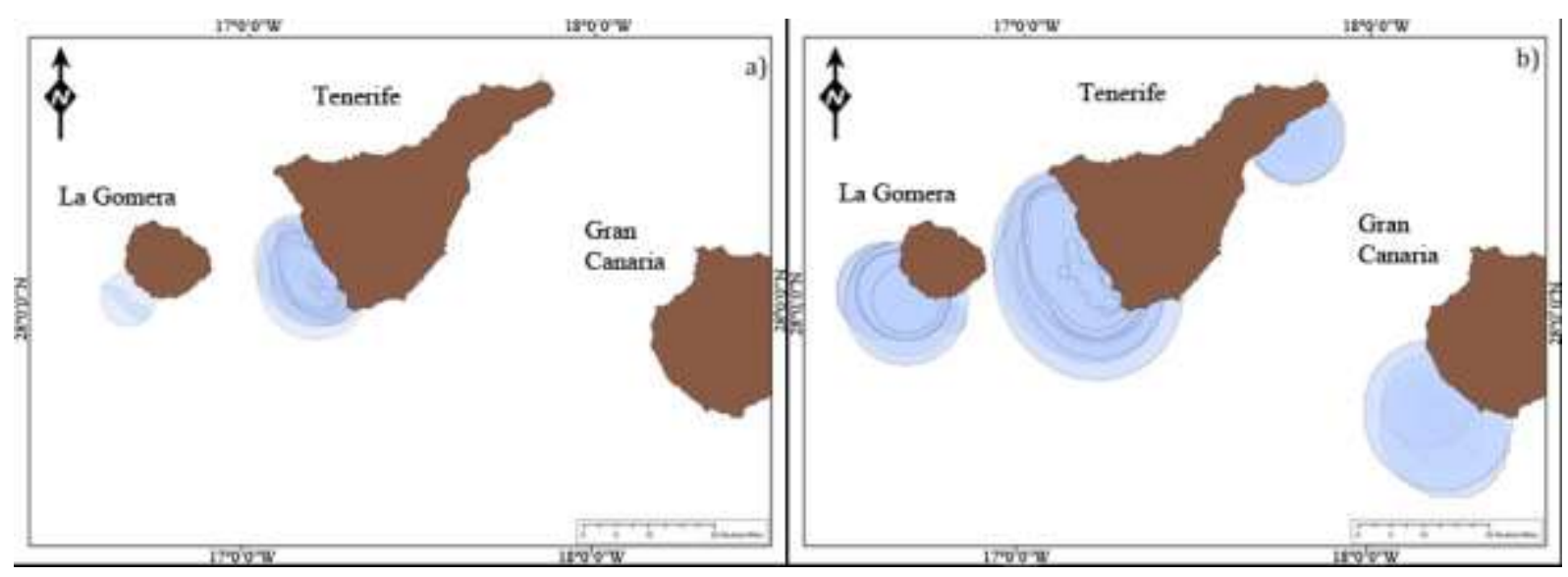

848 Fig 6a-b Ranging patterns of the 193 well-marked, adult and indeterminate SFPWs sighted at 849 least ten times, estimated by fixed kernel a) at 50\% UD and b) at 95\% UD 